\title{
PARECERES
}

\section{OPERAÇÃO INTERLIGADA - COMPETÊNCIA DO PREFEITO - ATO NEGOCIAL}

\section{PARECER}

\section{I - INTRODUÇÃO}

1. Versa a consulta sobre a constitucionalidade da Lei Rio $n^{\circ} 2.128$, de 18/04/94, na medida em que seu art. $7^{\circ}, I, \mathrm{c} / \mathrm{c}$ o art. $6^{\circ} . I$, dá atribuição ao Prefeito da Cidade do Rio de Janeiro, para, por meio de ato administrativo, realizar operação interligada, instituto urbanístico regulado por aquele diploma legal. quando se caracterizar a proposta, do interessado, como de interesse público.

2. $\mathrm{O}$ instituto em tela tem sua base normativa superior na Lei Complementar Rio $n^{\circ} 16$. de 04/06/92, que dispõe sobre a Política Urbana do Município e institui o Plano Diretor Decenal da Cidade do Rio de Janeiro.

2.1. Preceitua o art. 430 da Lei Orgânica Municipal que,

"para assegurar as funções sociais da Cidade e da propriedade, o Poder Público poderá valer-se"

de instrumento de caráter fiscal e financeiro; jurídico-urbanístico; urbanístico-institucional; e de caráter administrativo; instrumentos que o dispositivo elenca,

"além de outros que a lei definir".

2.2 No exercício dessa atribuição, o legislador local, na referida Lei Complementar. definiu (art. 18, III, b), como instrumento de aplicação do Plano Diretor, de caráter urbanístico,

" a operaçāo interligada", que definiu em seu art. 28 :
"Constitui operação interligada a alteração pelo Poder Público, nos limites e na forma definidos em lei, de determinados parâmetros urbanisticos, mediante contrapartida dos interessados, igualmente definida em lei."

A lei ordinária referida é. exatamente, a Lei Rio $n^{\circ} 2.128 / 94$.

2.4. Em nivel regulamentar, o Decreto Rio $n^{\circ}$ 12.959, de 06/06/94, instituiu a Comissão Especial para Análise da Operação Interligada. tendo sido sucessivamente alterado pelos Decretos Rio $n^{\circ}$ 15.838, de 20/06/97; 16.153, de 07/10/97; 16.711, de 04/06/98; $e$ 17.899, de 14/08/99.

O Decreto Rio $n^{\circ} 13.748$, de 14/03/95, instituiu o procedimento a ser observado para a aprovação da operação interligada.

3. O presente estudo desenvolverá, primeiramente, observaçōes sobre o direito de propriedade, e seus desdobramentos, os direitos de construir e de usar o bem imóvel urbano, a que se vincula o instituto considerado; em face da lei e do ato administrativo, e no contexto dos Direitos Constitucional, Administrativo, Social-Urbanístico e Edilício contemporâneos.

3.1. Em consonância com os princípios e regras destes ramos jurídicos, analisaremos a operação interligada, para, afinal, opinarmos, com base nos elementos precedentes, conclusivamente, sobre a questäo da constitucionalidade da Lei Rio $n^{\circ} 2.128 / 94$. 


\section{II - O DIREITO CONTEMPORÂNEO \\ DA PROPRIEDADE IMOBILIÁRIA URBANA}

1. O sentido social da Constituição de 1988 em nada abalou a identificação do direito de propriedade privada com direito básico inviolável da ordem constitucional da Naçāo brasileira, elencado, nesta qualidade, pelo $\mathrm{ca}$ put do art. $5^{\circ}$ da Carta Política, no mesmo patamar dos direitos à vida, à liberdade, à igualdade e à segurança, de que é cognato.

1.1. De todos esses direitos. incluindo aquele à propriedade, os demais, e correspondentes garantias, categorizados, constitucionalmente, como fundamentais, são, efetivamente, desdobramentos, como se depreende da própria configuração dada, pelo constituinte, ao citado art. $5^{\circ}$, e seus incisos: garantidos, no caput, aqueles direitos básicos, prescreve o dispositivo que tal garantia se dará

"nos termos seguintes",

ao que se adita a enumeração, em numerosos incisos, das modalidades em que se permenorizam aqueles direitos.

1.2. Na enumeração, reitera-se a garantia ao direito de propriedade $-n^{\circ} X X I I \rightarrow$, clausulando-o com uma função social $-n^{\circ} X X I I I$ - ou seja, com um comprometimento finalístico de não-violação ou de atendimento ao bem comum, sem que, como é curial, tal comprometimento abale a garantia constitucionalmente assegurada ao direito.

1.3. Reforça, a $C F$, a garantia à propriedade, ao prescrever, no inciso $X X I V$, que sua perda em relação a determinado objeto, e a restrição a seu conteúdo, só se farão por desapropriação, mediante o devido processo legal, com sua substituição, no patrimônio do expropriando, por justa indenização.

1.4. Pode dizer, com tranquiilidade, que, reproduzindo as garantias referentes à propriedade, na moldura tradicional do constitucionalismo brasileiro, a $C F$ de 88 robusteceu esse direito, e, correlatamente, uma das manifestações dele e da liberdade, no campo patrimonial-econômico, que é a livre iniciativa.

1.4.1. As disposições sobre a ordem econômica bem patenteiam essa realidade, eis que o art. 170 da $C F$ explicita, como um dos fundamentos daquela, a

"livre iniciativa", $e$

e como um de seus principios, a

"propriedade privada" ( $\left.\mathrm{n}^{\circ} \mathrm{I}\right)$,

gravada, uma vez mais, por sua

"função social" ( $n^{\circ}$ III).

sem quebra, contudo, reiteramos, da garantia de sua substância.

1.4.2. Ademais, o papel do Estado, em face da atividade econômica, foi diminuída, porquanto, não repetida a sua capacidade, constitucionalmente prevista nos regimes anteriores, da intervenção estatal no domínio econômico. limita-se ele a agente normativo e regulador, com funçōes de fiscalização, incentivo e planejamento, este meramente 'indicativo' para o setor privado (art. 174).

1.4.3. Não se pode olvidar que as sucessivas reformas constitucionais acentuaram, como é notório esse caráter liberalizante da economia, o que se verificou, especialmente, a partir da Emenda Constitucional $n^{\circ} 08 / 95$.

2. É fundamental grifar-se que, quando a $C F$ assegura o direito de propriedade, o faz em sentido amplo, abrangendo os direitos sobre todos os bens patrimoniais e não, apenas, os que sejam objeto de direitos reais. Direito de propriedade é, portanto, o direito de conteúdo econômico, o direito patrimonial.

2.1. Com efeito, a expressão direito de propriedade admite um sentido lato e um sentido estrito.

2.1.1. No primeiro, é como salientado, qualquer direito de conteúdo econômico, qualquer direito que tenha por objeto bens econômicos, isto é, com valor pecuniário.

2.1.1.1. O patrimônio (art. 57 do CC), como universalidade, abrange direitos que se refiram a bens econômicos. Assim, direito de propriedade 'lato sensu' é qualquer direito patrimonial.

2.1.1.2. Neste sentido, pode dizer-se que, ao invés de um direito de propriedade, existem direitos de propriedade.

2.2. Stricto sensu, o direito de propriedade é o domínio, a propriedade real (cf. art. 485 , in fine, do $\mathrm{CC}$ ), o mais amplo dos direitos reais ( $a r t .524$ do $C C$ ), e que engloba, em seu conteúdo, um feixe de direitos, poderes e fa- 
culdades, todos de índole patrimonial, e, portanto, todos, direitos de propriedade.

3. Em verdade, como direitos subjetivos que são, os direitos patrimoniais encerram poderes, como o de alienar, no caso do domínio, o de ceder, no caso do direito obrigacional; e faculdades, que traduzem, faticamente (fato e faculdade são cognatos, derivando ambos do mesmo étimo (fac'), a satisfação do interesse, a que, juridicamente, atende o direito subjetivo.

3.1. Referindo-se ao domínio, o art. 485 do CC alude a poderes inerentes à propriedade.

3.2 O conteúdo do direito marca a sua $e x$ tensão, define seu objeto, e compõe-se desses poderes e faculdades.

3.3. Por seu tumo, os atos e fatos praticados pelo seu titular, de acordo com tal conteúdo, dentro dessa extensão, são o exercício do direito.

3.3.1. O exercício dá-se, portanto, através de fatos, quando se trata de faculdades, como no caso da realização de obras de restauração de um edifício, efetuadas, pelo proprietário, no imóvel de sua propriedade; ou por atos jurídicos, quando se trata de poderes, como o de dispor, contido no domínio.

4. O art. 524 do Código Civil estabelece que

"a lei assegura ao proprietário o direito de usar, gozar e dispor de seus bens";

assim como o art. 525 estatui que a plenitude da propriedade compreende a reunião, no direito do proprietário, de

"todos os direitos elementares

da mesma; direitos esses, reiteramos, de cunho patrimonial, e, portanto, como expressão do direito de propriedade, constitucionalmente garantidos.

4.1. Dentre os direitos elementares do dominio imobiliário está o direito de construir, que, segundo o art. 572, confere ao proprietário a faculdade de

"levantar em seu terreno as construçōes que lhe aprouver",

respeitados

“o direito dos vizinhos e os regulamentos administrativos".

5. A propriedade, como instituto jurídico, como direito institucionalizado, tem, na lei, a definição de seu conteúdo. No caso do domínio. a lei é que dá a configuração desses direitos elementares, desse poderes e faculdades, que são seu objeto.

5.1. No que tange ao conteúdo dos direitos patrimoniais, a União Federal é a competente para dispor sobre os de índole civil, como é o caso do domínio imobiliário urbano: art. $22, I$, da $C F$.

5.2. Assim, preceituar que os direito de usar e de construir integram o conteúdo do dominio; ou se passará o último a constituir direito autônomo, como ocorre na Itália, é matéria de direito civil, e, portanto, da competência legislativa federal privativa.

5.3. Nesta linha, é, igualmente, da exclusiva alçada federal a fixação, em qualquer das duas hipóteses citadas, do conteúdo desses direitos, com o estabelecimento do respectivo contorno.

5.4. O usus (uso), em sua configuração máxima, é, ao lado do fructus (gozo) e do abusus (disposição), elemento do conteúdo do direito de propriedade: art. 524 do Código Civil, segundo o qual é assegurado ao proprietário o direito de usar, gozar e dispor de seus bens.

Está-se, no primeiro caso, perante o ius utendi, que é o direito, do proprietário, de usar da coisa; o direito de dela tirar todos os serviços que o bem pode prestar, dentro das limitações legais, sem que haja modificação em sua substância (MARIA HELENA DINIZ, Código Civil Anotado, São Paulo, Saraiva, 1995, p. 400).

O proprietário, que usa, retira da coisa as utilidades, que nāo os frutos: "Na mesma fazenda, usa-se a casa de moradia e desfrutase a horta" (PONTES DE MIRANDA, Tratado de Direito Privado, São Paulo, RT,. 3" ed., 1983, XIX: 79).

5.5. Insistamos no teor do art. 572 do Código Civil, consoante o qual

"o proprietário pode levantar em seu terreno as construções que lhe aprouver."

5.5.1. Expressiva, a propósito, a lição de DIOGO DE FIGUEIREDO MOREIRA NETO (Introdução ao Direito Ecológico e ao Direito Urbanístico, Rio, Forense, 1975, p. 94), que afirma que, nos termos da legislação civil, garantida pela $C F$, o que há é mais do 
que um direito de construir, mas uma liberdade de construir, decorrente da prescrição do art. 572 do Código Civil, que, como acentua o Autor,

"declara que o proprietário pode levantar, em seu terreno, as construçōes que the aprover o ordenamento jurídito não faz mais que enfatizar uma liberdade - a de construir"

5.5.2. No mesmo sentido, o clássico HELY LOPES MEIRELLES (Direito de Construir. São Paulo, RT, p. 14/15), que afirma, categoricamente, que

"a liberdade de construir é a regra. As restrições e limitações ao direito de construir formam as excȩ̧ōes."

6. Essas limitações dizem respeito ao exercício do direito de propriedade, ou seja, dos direitos (poderes e faculdades) elementares, que compõem o seu conteúdo.

6.1. O balizamento desse exercício tem um parâmetro genérico, comum a todos os direitos. e que é a sua regularidade, a traduzir a sua licitude, pela legitimidade, moralidade, razoabilidade e proporcionalidade; sendo sua face patológica o abuso do direito: não constitui ato ilícito o

"exercício regular de un direito reconhecido" (Código Civil, art. 160, 1)

7. No caso do donínio imobiliário, a Uniāo Federal, competente para legislar sobre este direito de caráter civil, ao dispor sobre o respectivo conterido, tem em mira possibilitar a coexistência dos vários direitos idênticos, ou conexos, titularizados por diferentes pessoas. Mas já estabelece, outrossim, limitações a seu exercício, com of fim de viabilizar o coexercício desses mesmos direitos.

7.1. No caso do direito de construir, o Código Civil o faz, ressalvando, no citado art. 572, os direitos de vizinhança, e disciplinando-os, nos arts. 554 e seguintes.

8. Não é, porém, apenas, o Direito Privado que trata das limitações ao exercício - não, ao contéido - do direito de construir, dos direitos elementares do dominio imobiliário.

8.1. Por isso, o próprio Código Civil, no mesmo art. 572, ressalva a incidência, no caso, dos

"regulamentos administrativos",

isto é, da legislação - leis e regulamentos - de Direito Administrativo, e, portanto, de Direito Público.
8.2. É que as limitações ao exercício do direito de construir, como, de resto, de outros direitos, podem, igualmente, decorrer da necessidade de salvaguardar interesses públicos cuja tutela é distribuída pelas várias pessoas políticas (e não, necessariamente, da competente para estabelecer o estatuto básico do direito em questão), interesses como a higiene, os bons costumes, a segurança, a tanquiilidade comunitária etc. Na medida em que o exercício dos direitos interfere com tais interesses, a pessoa política competente pelo seu respectivo velamento, exerce seu poder de polícia administrativa.

8.2.1. Primeiramente, ainda em nível normativo, por meio de edição de normas legais e de regulamentos administrativos, dispondo sobre a proteção daqueles interesses, e disciplinado, em consequiência, o exercício dos direitos.

8.2.1.1. Essá regulação normativa de polícia traduz-se em limitações de direito públi$c o$ as chamadas limitações administrativas, de Direito Administrativo.

8.2.1.2. As limitações administrativas dão, em verdade, sentido expresso à regularidade do exercicio dos direitos, na defesa do interesse público.

Quanto mais espontânea e autêntica for a sensibilidade da comunidade para esse interesse, menor terá de ser o número de normas de polícia.

8.2.1.3. As limitaçōes de direito público provêm do Direito federal ou do local, nos lindes das respectivas atribuições; de acordo, portanto, com o interesse salvaguardado.

Mesmo quando emanam do legislador federal, porque competente em ambas as áreas - a da fixação do conteído e a do poder de policia, limitativo do exercício - distinguem-se, pela razões expostas, os contornos de conteúdo. de direito civil; e as limitações de exercício, de direito administrativo.

8.2.2. Mas o poder de polícia administrati$v a$ não se manifesta apenas, por intermédio de atos gerais, mas também, e muito especialmente. por atos de realização, de concretização do Direito (atos especiais).

8.2.2.1. Os primeiros estabelecem condições gerais de exercício dos direitos e disciplinam o modo de atuação das autoridades administrativas. 
8.2.2.2. Os últimos concretizam situações jurídico-administrativas, quer perınitindo a atividade privada (autorizaçōes, permissões, licenças); quer determinando a conduta individual (ordens, exigências administrativas: quer vedando algumas atividade (proibições).

8.2.3. É que a atividade administrativa desenvolve-se em progressiva concretização: parte da edição de normas regulamentares, passando à prática dos alos juridicos adıninistrativos de realização do direito, unilaterais, bilaterais e multi ou plurilaterais, inclusive os de indole negocial: e chegando, a final, aos fatos administrativos, aos atos materiais.

8.3. Tópico fundamental. nesta matéria, é o dos limites às limitaçoes administrativas. inclusive os direito de construir e de usar o imóvel urbano.

8.3.1. Sublinhemos que esses direitos são. pelo Direito Civil, sua sede, direitos elementares, inerentes ao domínio imobiliário, especialmente, quanto ao de construir, o urbano: e seu exercicio, no atendimento da condicionante da finção social da propriedade, uma obrigação, tanto que o Poder Priblico municipal pode impor a edificação compulsória ao proprietário do solo urbano. na moldura do art. $I 82, \$ 4^{\circ}$, e seu inciso $I$, da $C F$, de modo a atender a utilização para a qual está rocacionado o imóvel citadino.

8.3.2. O exercício dos direitos de usar e de construir corresponde. pois à exercitaçāo de direitos integrantes do direito de propriedade subjetivamente garantido pela Constituição Federal, sob o aspecto chamado da conservação individual, que impede que seu titular possa ser dele privado - salvo por desapropriação indenizatória - como direito subje. tivo, adquirido, que é.

8.3.3. Recordemos, outrossim, que, pelo art. 572 do Código Civil. " o proprietário pode levantar em seu terreno as construçōes que lhe aprouver, salvo o direito dos vizinhos e os regulamentos administrativos".

8.3.4. Reproduzamos a lição de PONTES DE MIRANDA (Tratado de Direito Privado, São Paulo, RT, $4^{a}$ ed.. 1983. XIII: 378), que preleciona que, na regra. logo ressaltam tese e antítese: cada um, no seu terreno, constrói o que entende, como entende e quando enten- de (é a liberdade de construir, enfatizada por DIOGO DE FIGUEIREDO MOREIRA NETO P por HELY LOPES MEIRELLES, conforme já salientado) (tese); o interesse 'dos vizinhos' - e não de 'cada vizinho' e o interesse público têm de ser atendidos (antitese).

8.3.5. O que há, pois, é a limitação do exercício de um direito subjetivo, e, como toda limitação, deve ser a menos gravosa possível, no balanceamento, em termos de ação ou inação, entre o direito do proprietário e o do conjunto dos vizinhos e o interesse público.

8.3.6. Sublinhemos que as limitações de exercicio dessa liberdade, devem obedecer aos festejados princípios da razoabilidade e da proporcionalidade, básicos no campo do poder de polícia administrativa, devendo ser, repetimos, os menos restritivos.

8.4. Ademais - e este é outro ponto básico -, embora previstas essas limitaçōes, em princípio. genericamente, há-de se dar espaço para sua adequação ao caso concreto.

8.4.1. Destarte, no sopesamento de interesses - e o Direito se concebe e se realiza neste permanente processo de composição, de harmonizaçāo de interesses -, entre, de um lado, o direito privado, subjetivo, constitucionalmente garantido, do proprietário, e, em princípio, de exercício pleno: e, de outro, o interesse público, traduzido em limitaçōes, genericamente estabelecidas, há-de abrir, efetivamente, lugar para a aferição individualizada, no caso concreto.

8.4.2. Sabemos que a marca contemporânea da Teoria Geral e da Filosofia do Direito é no sentido da valorização do caso concreto.

O Direito e'm tese é abstração, é 'meio-direito'. é a 'regra' em potência, com mera aptidão para incidir, uma vez ocorrente o fato gerador hábil.

A norma jurídica, esta só existe, só se aperfeiçoa, só se consuma, quando incide a regra sobre o fato e tem lugar a conjugação desse fenômeno com a da libertação da energia juridica. da força que emerge desse mesmo fato, na plenitude da realidade trazida na parêmia 'ex facto oritur ius'.

8.4.2.1. O Direito completo só existe, em verdade. quando regra e energia factual, ao 
convergirem, produzem uma resultante, que é a realização, a concretização jurídica, na situação já então individualizada, e essa é que tem de ser analisada e apreciada.

8.4.3.Salientemos, portanto, desde agora, o que desenvolveremos adiante: no campo de atuação governamental, o Poder Executivo é, por excelência, aquele que lida com o caso concreto.

9. O tertium genus do Direito Contemporâneo, o Direito Social, também incide na matéria.

9.1. Como é próprio desse mais recente ramo jurídico, ao invés de considerar o sujeito de direito, enquanto indivíduo: ou, no contexto estatal, na qualidade de governante ou governado; o ius sociale o tem na condição de membro da sociedade, de um grupo social, de uma classe, de um conjunto comunitário.

9.1.1. A par da chamada sociedade civil organizada, das instituiçōes desta. há, é certo, forte presença do Poder Público. na sua função de participação social, de velamento e efetivação de direitos transindividuais - difusos, coletivos, comuns de todos - e individuais indisponiveis.

9.1.2. Nesta sua atuaçāo, o Estado exerce a função legislativa, ao editar as normas de Direito Social, e a função jurisdicional, ao julgar os respectivos litígios.

Mas as diferentes parcelas da função administrativa também interferem: a atuação, através do exercício do poder regulamentar, e por meio da prática de atos administrativos concretos.

9.2. A parte do Direito Social, que engloba a propriedade imobiliária, é o Direito Urbanístico, cuja autonomia a $C F / 88$ proclamou, ao nominá-lo, diferenciando-o de outros ramos juridicos, no art. $24, I$.

9.2.1. O Direito Urbanístico é a disciplina jurídica do urbanismo e da atividade urbanistica, que objetivam a adaptação e a organização do espaço natural, fazendo-o fruível por uma comunidade citadina. no desenvolvimento das funçôes elementares da habitação, do trabalho, da recreação, da saúde, da segurança, da circulaçāo e outras (cf. art. $422, \S \S 1^{\circ} \mathrm{e} 2^{\circ}$, da Lei Orgânica do Município do Rio de Janeiro).
9.2.2. O urbanismo, enquanto ciência, técnica e política, envolve: (a) a política urbana, de que resulta o planejamento, ou seja, a fixação, por opções axiológicas, com base nos elementos técnico-científicos, de metas e fins a serem atingidos, e dos meios e diretrizes para fazêlo; $(b)$ a ordenaçāo dos espaços, com a adequação de seu parcelamento, ocupação, construçāo e uso; (c) fiscalização e controle - prévios, sucessivos $e$ repressivos - dessas atuaçōes; (d) o incentivo, o fomento destas atividades; (e) a intervenção ou interferência urbanistica, por meio de instrumentos coativos unilaterais, como a edificação compulsória (art. $182, \S 4^{\circ}$, da CF); (f) e, básico neste estudo, a negociação, no chamado 'urbanismo contratado' ou 'urbanismo concertado', conforme será adiante desenvolvido.

9.2.3. O sentido social da propriedade está presente, seja no Direito Civil, seja no Público, e, obviamente, no Social.

9.2.3. I. No primeiro, ao proteger os direitos dos vizinhos: ao prescrever que se respeitem os regulamentos administrativos.

9.2.3.2. No segundo, porque o poder de polícia administrativa sempre foi, com efeito. o segmento, da atividade administrativa, que tem endereço social mais evidente, mesmo quando ainda inserida nos limites tradicionais da salubridade, da tranquiilidade, da segurança.

9.2.4. No Direito Urbanístico oferece-se. em modalidade conspícua, o condicionamento do domínio imobiliário urbano à sua função social.

9.2.4.1. É certo, porém, que esse condicionamento está, por seu turno, bitolado pela $C F$. que, especificamente sobre o ponto, prescreve, em seu art. $182, \S 1^{\circ}$, que

" a propriedade urbana cumpre sua função social quando atende às exigências fundamentais de ordenação da cidade expressas no plano diretor."

9.2.4.2. Este, o Plano Diretor, reveste-se, portanto, de essencialidade, no balizamento da função social, da propriedade imobiliária urbana: na atribuição de conteúdo à política urbana; e, portanto, na atuação do Poder Público na matéria.

9.2.4.3. Acentuemos, desde logo, que, con- 
forme citado, é o Plano Diretor carioca que instituiu a operação interligada, e lhe dá a configuração básica.

9.3. Se legislar sobre o direito urbanístico é da competência concorrente federal e estadual, nos termos do disposto no art. 24, I, da $C F$, esta reserva, e outras capacidades normativas da Federaçāo Brasileira, alguns setores específicos.

9.3.1. Nesta linha, pelo art. $21, I X$, compete à União.

"elaborar e executar planos nacionais e regionais de ordenação do território."

9.3.2. Igualmente à União cabe, na moldura da regra do inciso $X X$ do mesmo artigo.

"instituir diretrizes para o desenvolvimento urbano, inclusive habitação, saneamento básico e transportes urbanos."

9.3.3. Especificamente aos Estados é atribuído, pelo art. $25, \S 3^{\circ}$.

"instituir regiōes metropolitanas, aglomerações urbanas e microrregiões, constituídas por agrupamentos de Municípios limítrofes, para integrar a organização, o planejamento e a execução de funçōes públicas de interesse comum."

9.3.4. Mas, certamente, papel de especial relevo é reservado aos Municipios, a que, por excelência, está ligada a figura da cidade.

9.3.4.1. Compete-lhe, por isso, segundo as disposições do art. 30, além de

"legislar sobre assuntos de interesse local" $\left(n^{\circ} \mathrm{I}\right)$, e de

"suplementar a legislação federal e a estadual no que couber" ( $\mathrm{n}^{\circ}$ II);

em específico

"promover, no que couber, adequado ordenamento territorial, mediante planejamento $e$ controle do uso, do parcelamento e da ocupação do solo urbano" ( $\mathrm{n}^{\circ}$ VIII).

9.3.4.2. Por seu turno, pelo art. $182, \S 1^{\circ}$, cabe à Câmara Municipal aprovar, exatamente, o Plano Diretor, que

"é o instrumento básico da política de desenvolvimento e de expansão urbana."

9.3.4.3. O caput do mesmo artigo dispõe, a propósito, que essa

"política de desenvolvimento urbano, executada pelo Poder Público municipal, conforme diretrizes gerais fixadas em lei, tem por objetivo ordenar o pleno desenvolvimento das funçöes sociais da cidade e garantir o bemestar de seus habitantes."

10.0 direito de construir, que deita suas raizes, conforme visto, no Direito Civil, e se desdobra no Direito Administrativo - mediante o poder de policia administrativa, regulaınentar, e de concretização, e no Direito Urbanístico - com seus institutos próprios, como o solo criado, o parcelamento, o zoneamento, a eficificação compulsória, a operação interligada - é objeto de um conjunto normativo híbrido, denominado Direito Edilício.

10.1. A configuração do Direito Edilício tem base nos elementos antes analisados, dentre os quais destacamos os que se seguem, na medida em que interessam, mais de perto, ao direito de usar e de construir.

a) a raiz civil desses direitos, com o sentido de liberdade de usar e de construir,

b) sua natureza de direitos patrimoniais, expressão do direito de propriedade que são, constitucionalmente garantido;

c) seu comprometimento, em razão, da função social da propriedade;

d) o cumprimento dessa função, no tocante à propriedade imobiliária urbana, quando atendidas as exigências do Plano Diretor municipal;

e) as limitações administrativas a esses direitos, que hão-de ser as menos gravosas possíveis; e o são de seu exercício, e não de seu conteúdo, a envolver a edição de atos administrativos regulamentares e a prática de atos administrativos de realização do direito, sempre com adequação ao caso concreto, inclusive autorizaçōes, eu permitem a prática de fatos, o exercício de atividade que, sem sua cobertura, seriam antijuridicas, funcionando, a autorizaçāo, como excludente de antijuridicidade;

f) seja na sua vertente de Direito Civil, seja naquele de Direito Administrativo, ou na do Direito Social Urbanístico, a negociabilidade, que é, contemporaneamente, característica inafastável desses ramos jurídicos.

11. No desenvolvimento do presente estudo, é mister salientar neste passo, que, quer o Direito Privado, como lhe é ínsito; quer o 
Direito Administrativo quer, ainda, o Direito Social, e o seu ramo, que é o Direito Urbanístico, caracterizam-se, na contemporaneidade, pelo caráter negocial das relaçốs juridicas de que o Poder Público participa, quanto aos direitos de usar e de construir, em sede de donínio imobiliário urbano.

11.1. No conjunto interseção desse complexo de ramos jurídicos, o Direito Edilicio tem. portanto, em grande parte. uma condução negociada.

11.2. Este dado é absolutamente fundamental. porque, como pormenorizado adiante, a operação interligada tem natureza negocial.

11.3. O Direito Privado sempre foi o campo tradicional dos atos negociais, de subjetivação jurídica: portanto. dos atos criadores daquilo que se costuma chamar de situações jurídicas subjetivas, que são as situaçōes jurídicas personalizadas, individualizadas, criadas pelos sujeitos de direito, e com a virtude, muito importante. da intangibilidade. da imutabilidade. salvo. é claro, quando possível, a alteração pelo consenso das partes. É o paraíso da garantia da segurança juridica. e, por isso mesmo, é ele. o Direito Privado, o direito do individualismo juridico, do liberalismo.

Em primeiro lugar, a liberdade na criação e formataçióo das sinuaçōes jurídicas: e. depois, de um lado. a salvaguarda da permanência e da proteção dos direitos. e. de outro. a compulsoriedade do cumprimento das obrigações. Nisso residem. enfim. os motivos e o campo fértil para o desenvolvimento do individualismo. na legítima proteção dos direitos dos particulares.

Por isso mesmo, o negócio jurídico, representado por atos negociais de várias espécies, sobressai no Direito Privado, veiculado, não só pelo contrato, mas também pelos atos unilaterais autovinculativos, como as declarações unilaterais de vontade, as promessas de recompensa.

11.3.1. É certo, porém. que, no Estado Intervencionista, tisnou-se a autonomia da vontade, inclusive, por exemplo, pela presença de contratos compulsórios. de contratos-tipo.

11.4. Já no Direito Público Antigo, as situações jurídicas nele mais comuns eram, diver- samente, as chamadas situações juridicas objetivas, também ditas sinuações juridicas estatutárias, legais ou regulamentares, que têm as características opostas às das situaçōes jurídicas subjerivas.

Elas se caracterizam, ao contrário da personalização e da individualizaçāo, pela generalização, marca da identidade, ou, como diz PONTES DE MIRANDA. da mesmeidade, ou seja, é a mesma a situaçāo para todos aqueles que são nela investidos, como a do servidor público; do usuário em geral dos serviços públicos; dos jurisdicionados do poder de polícia.

Exatamente por ser objetiva a situação; por encontrar-se seu contéido de direitos, poderes e deveres na regra juridica, no Direito Objetivo, no Direito Positivo, caracteriza-se ela por sua mutabilidade. Mudando a norma, altera-se o conteúdo dos poderes e deveres que constituem o material componente da situação jurídica

11.5. É certo, porém, que sempre houve. no Direito Público, u'a margem de subjetivaçāo.

Na medida, por exemplo, en que o tempo vai passando e o serviço sendo prestado. há uma incorporação de direitos ao patrimônio jurídico do servidor. Mas tudo isso com muita parcimônia, não só no reconhecimento pela proclamação doutrinária, mas na própria chancela jurisdicional.

11.5.1. É claro que o contrato sempre teve lugar, também, no serviço público, mas o publicista não ficava à vontade com a figura contratual, isto porque, ao lado da característica de conter situações jurídicas regulamentares, o Direito Público sempre foi marcado pela unilateralidade da atuação do Poder Público, pela imperatividade desta mesma atividade, pela sua auto-executoriedade, pela revogabilidade dos atos, pelo exercício do poder regulamentar, que enriquece, ainda mais, o conteúdo das situações juridicas objetivas: tudo isso, é claro, mesmo no Estado de Direito. levando-se em conta a autovinculação e os limites pertinentes.

11.5.2. Na exposição de Motivos do Decreto-lei $\mathrm{n}^{\circ} 2.300$, que foi o antecessor da atual Lei de Licitações, a Lei $n^{\circ} 8.666 / 93$, o então Ministro da Justiça, Saulo Ramos destacou 
um trecho que reproduz bem essa mentalidade publicista, ao dizer que os contratos administrativos, sujeitos a regime juridico especial. deferiam à Administraçăo Pública, que deles participava com supremacia de poder, com prerrogativas, extraordinárias. traduzidas formalmente nas denominadas "cláusulas exorbitantes" ou "derrogatórias do Direito Comum". Sempre consideramos, aliás. essa, uma expressão inadequada, porque o que derroga ou exorbita sai do campo do Direito Comum, para entrar no campo do Direito de Exceção.

11.5.3. O Ministro citava THEMísTOCLES BRANDÃO CAVALCANTI, primieiro grande sistematizador do nosso Direito Administrativo nas décadas de 30 e 40 , e dizia ser justa sua observação. ao abordar tema de tăo profundas dificuldades. quando sustentava: "A teoria dos contratos administrativos constitui um dos pontos mais importantes no estudo do Direito Administrativo, não somente pela relevância de sua aplicação, mas, ainda, porque aqui se encontra a fronteira menos definida do Direito Público com o Direito Privado". É, portanto. um trecho bastante expressivo. que mostra a perplexidade que havia. à época, en torno do tema contrato no Direito Público.

11.5.4. É certo, todavia. que. além do contrato, embora com esse caráter hibrido, sempre se reconheceu a existência de outros atos administrativos negociais: (a) bi ou plurilaterais, como convênios, acordos, ajustes; e (b) unilaterais, em que o conteúdo e os efeitos jurídicos são queridos pela Pública Administração e pelo administrado. que requereu sua prática ou aderiu à sua eficácia: atos unilaterais esses, dentre os quais sempre se colocaram a autorização. licença, a demissão.

11.6. No campo do Direito Social, de um lado sempre tivemos contratos, contrato individual de trabalho. o contrato coletivo, produto, exatamente, da negociação.

Mas. por outro lado. se dava a presença forte do Estado Intervencionista, do Estado Providência.

A presença desse tipo de Estado se caracterizava. exatamente, pela expedição de atos unilaterais.
Mesmo no campo do Direito Econômico, a própria "intervenção do Estado no domínio econômico" mostrava que se tratava de uma atividade imperativa, tipicamente de soberania. Assim, também no Direito Social, se mesclavam os aspectos unilaterais, regulamentares e imperativos, com as figuras contratuais.

11.7. A modernidade trouxe, entretanto, para o nosso Direito e para o Direito Comparado em geral, modificações radicais nesta área.

11.7.1. Com o esgotamento do Estado Intervencionista na sua expressão máxima: com o crescimento da noção de cidadania, de participação na coisa pública, que é a razāo de ser e a tradução da noção de República; com o desejo inafastável de eficiência, de eficácia. de economicidade, em termos de atuação do Poder Público e de atendimento aos interesses públicos e particulares; tudo isso fez com que se constasse que essa espécie de atuação governamental não tinha produzido os frutos que se desejavam, tendo em vista a consecução do interesse comum e do interesse individual.

11.7.2. Com o pano de fundo da globalização, da desregulamentação, da privatizaçāo. da clesestatização, e na busca de um Estado e de uma sociedade mais eficientes: de uma sociedade mais harmônica, uma das veredas para que isso se possa tornar realidade é a superação do Estado unilateral, impositivo, ainda que paternalista em certos pontos, para se fazer um Estado que seja co-participe, com o cidadão, na própria criação e execuçāo do Direito.

Há, assim, a diminuição e a substituiçāo progressivas do campo da unilateralidade, da imperatividade, em favor da consensualização, da negociação, mercê da auto-regulamentação, pelas partes, de seus legítimos interesses, como é próprio dos negócios jurídicos. com a conseqüente subjetivação das situaçōes.

11.7.3. Essa consensualização e subjetivaçāo fizeram retornar o Direito Privado a seu curso próprio: e marca, indelevelmente. o Direito Público e o Direito Social Contemporâneos; muito especialmente, no campo dos direitos de cunho econômico, dos direitos pa- 
trimoniais, como é o caso do direito de propriedade, e de seus direitos integrativos elementares, muito especialmente, do direito de usar a propriedade imobiliária urbana, e o de nela construir.

Daí, falar-se em "economia concertada", em "economia contratada", que são traduções da co-participação do setor público e do setor privado. Lembremos, por exemplo, da livre negociação de empregadores e empregados, no Direito do Trabalho, caracterizado hoje, pelas "rodadas de negociações".

É a era da já apontada desregulamentação, 'deslegislação'; e, em conseqüência, das parcerias, da terceirização, da co-participação.

11.7.4. Trata-se fenômeno mundial, e nele o Brasil já se engajou.

É o fenômeno da negociação, da subjetivação jurídica do Direito Público e do Direito Social, superando-se, portanto, em grande dose, a objetividade, o caráter estatutário, regulamentar, do seu universo.

Todo aquele poder de império, quer no campo específico do Direito Estatal, quer no do Social, cede lugar a essas formas consensuais de co-atuação.

11.7.5. Para citarmos um grande autor ibérico, CABRAL DE MONCADA (Direito Econômico, Coimbra Editora, $2^{2}$ ed., 1988, p. 379 e s.). podemos dizer que. hoje, o negócio jurídico, o contrato, o consenso, é uma das formas normais de exercício da soberania.

Não se trata de arredar a soberania: cuidase de integrar o cidadão, a empresa, enfim, os vários agentes da sociedade, no próprio exercício da soberania, superando, de certa forma, esta distinção entre Direito Público, Privado e Social; entre o setor público e o setor privado da Economia, na formação de um universo comum.

11.7.6. Tudo isso, portanto, está a mostrar que o caminho da participação se dá, modernamente, no caso do Direito Público e do Direito Social, através da bilateralização ou multilateralização negocial. É, mais do que propriamente a contratualização formal, eis que, mesmo não havendo a figura específica do contrato, mesmo em se tratando, às vezes, de atos unilaterais, estamos diante de situa- ções de subjetivação, de individualização, de personalização, que foram produto de consenso, de trativas, de acordos, de compromissos, de protocolos, de ajustes.

Enfim, há toda uma série de espécies de co-participação do Poder Público e do particular, no Direito Público e no Direito Social, no processo de criação das situações jurídicas, e na sua vivência e sua execução.

11.7.7. Esta negociação está presente nos vários segmentos dos ramos jurídicos em tela.

Quando presente o Poder Público, no rela. cionamento jurídico, a diminuição de intensidade e do campo de abrangência do ius imperii faz renascer a distinção entre esse e o ius gestionis, a reduzir atributos e prerrogativas do Poder Administrativo, como as da imperatividade, da auto-executoriedade, que cedem lugar a uma visão gerencial da Administraçāo Pública.

A desregulamentação, a privatização. a terceirização e as parcerias levam a que os negócios jurídicos, em lugar dos tradicionais atos administrativos imperativos, passem a povoar o mundo jurídico da atuação estatal.

11.7.8. Assim, ao lado dos contratos administrativos, clássicos, a própria permissão de serviço público, que sempre foi considerada uma forma de ato unilateral, revogável, precário da Administração, passou, pelo artigo 175 da Constituição Federal, e pela própria legislação específica sobre a matéria, em nível infraconstitucional, a ter caráter contratual.

11.7.8.1. Na área do servidor público, sempre tivemos os coletistas em situação jurídica contratual, e ainda os temos em vários setores. Mas, ainda mais interessante que os celetistas, que nada mais são que empregados do Direito do Trabalho no campo do Poder Público, vamos encontrar, hoje, o contrato administrativo de trabalho, ou seja, uma espécie contratual, administrativa, que difere do contrato de prestação de serviços, porque o prestador de serviços continua sendo um terceiro em relação à Administração, enquanto o contrato administrativo de trabalho posiciona o contrato como servidor público, não se tratando, porém, do contrato de trabalho, de Direito Laboral, nem da situação estatutária 
típica do servidor público em geral. Desenvolveu-se, com este caráter, o contrato temporário, previsto no artigo $37, \mathrm{IX}$, da Constituição Federal.

11.7.8.2. Na organização administrativa, o negócio jurídico também passou a estar presente. Até então, a organizaçāo administrativa se caracterizava pela hierarquia, na Administração Direta, e pela tutela ou supervisão administrativa, no relacionamento da Administração Direta com a Indireta ou Fundacional.

A tutela e a hierarquia, apesar de todas as forças centralizadoras que prevalecem no País, estāo cedendo lugar, em nossa Administração Pública, a partir do Direito Comparado, às figuras consensuais que buscam, exatamente, a criação do que os autores chamam de cultura da empresa em termos administrativos, ou seja, a modernização, a mentalidade empresarial em sede de Administração Públi. $c a$, não só quando ela se organiza em empresas públicas e sociedades de economia mista, mas também em sede de Administração Direta, Autárquica e Fundacional. E surgiu o contrato de gestão, consagrado, já agora em nível constitucional, em função do disposto no $\$ 8^{\circ}$ do art. $37 \mathrm{da} C F$, a prestigiar a autonomia gerencial, de órgãos e entidades, o que conduz. necessariamente, à capacidade de negociação, sob pena de não se atingirem as metas de eficácia, eficiência, economicidade, também contempladas constitucionalmente: arts. 37, caput, 70 e 74, II.

Tudo isso a valorizar a apreciação das peculiaridades do caso concreto, a consecução do interesse público e sua harmonização com o privado, 'in casu'.

11.7.8.3. Em se tratando, especialmente, de Direito Econômico, de direitos patrimoniais, a negociação, a consensualizaçāo têm tido, de modo conspícuo, sua importância engrandecida, no atual Direito Brasileiro e no de outros Países. Nas palavras de CABRAL DE MONCADA (op. cit., p. 45/46), nesta perspectiva, o estado não mais atua sempre

"de forma impositiva e unilateral, antes adotando um atitude convencional para lograr os seus fins, através de recursos a técnicas consensuais. A intervenção do Estado revela, sim, uma certa privatização das suas formas, contratos-programas, contratos de preço, contratos de desenvolvimento para exportação etc., de que resulta, em boa medida, a especificidade do Direito Público da Economia. O contrato é, hoje, um meio normal de exercício da soberania. A razão de ser da opção estatal pela utilização de formas contratuais e paracontratuais - fenômeno conhecido pelo nome de economia contratual - ai donde dantes os Poderes Públicos emitiam atos unilaterais regulamentares e imperativos, reside no fato de que por este processo se assegura uma maior eficácia da decisão pública, relativamente à Economia. Na verdade, a decisão pública passa pela mediação do seu destinatário, que passa a estar interessado na elaboração e execução dessa mesma decisão. O particular tem, assim, não só acesso ao processo de produção e aplicação das normas, como também se atribui à sua vontade caráter constitutivo da ação administrativa, ou seja, a vontade jurígena, a vontade do usuário, neste caso do agente econô. mico, atuando com caráter constitutivo da ação administrativa, reduzindo-se as zonas de friç̧ão entre as autoridades administrativas e os particulares, e eliminando-se, assim, resistência da parte destes, e acelerando-se a integração político-social de certas zonas muito importantes da vida social e econômica que os Parlamentos têm dificuldade em representar fielmente. Deste modo, o Direito Público da Economia dá testemunho de novas exigências de participação e democracia direta e de integração política da atividade econômica. Este fato tem provocado uma certa crise na Teoria Geral do Direito Administrativo clássico, no tocante à caracterização da atividade administrativa como atividade preferencialmente unilateral, surgindo um apreciável conjunto de autores a propor novias tipologias da atividade administrativa, suscetíveis de abranger estes novos fenômenos convencionais; a propor novos conceitos de atos jurídicos específicos do Direito Público e Econômico. Sob o aspecto funcional, $o$ interesse desses processos convencionais, de fomentar a intervenção dos Poderes Públicos na Economia, consiste no clima de paz social e de concórdia que são suscetíveis de criar e 
desenvolver: A participaçāo dos particulares na criação e execução do Direito Administrativo e Econônico é um processo seguro de evitar conflitos com as autoridades e de eliminar resistências à execução das normas de Direito Administrativo".

11.7.9. No campo do Direito Urbanístico, e no do Direito Edilício, já se salientou a existência do 'urbanismo contratado', a 'gestão urbanística negociada"; da "urbanização consorciada".

11.7.9.1. Lembremos que, a figura da transferência do direito de construir é exemplo de contratualização do Direito Urbanístico.

Também o solo criado envolve a aquisição do direito de construir.

11.7.9.2. CAIO TÁCITO (O Direito de Propriedade e o Desenvolvimento Urbano, 'in' Temas de Direito Público, Rio, Renovar, 1997. 1: 588) alude. com o proverbial acerto, a propósito do solo criado, à "negociabilidade do acréscimo de pisos artificiais excedentes ao coeficiente de aproveitamento dos imóveis urbanos a importar em uma espécie de transaçāo liberatória da restrição de construir além do solo natural".

11.7.9.3. O caráter consensual do Direito Urbanístico é reconhecido em expressivo voto do Ministro ILMAR GALVÃO, que. na qualidade de Relator do RE ${ }^{\circ} 212.780-9 / R J$ (BDM, no 04/2000, p. 301), assevera:

"A aprovação de um projeto de loteamento e construção pelos órgãos competentes do Poder Público tem muito que ver com uma espécie de contratação celebrada entre o proprietário do imóvel e a muncipalidade."

12. É neste moderno contexto jurídico, social e econômico, que se inscreve, com pertinência, o instituto urbanístico da operação interligada, e da consensualidade da co-atuação do particular e do Poder Público Municipal. no tocante à mesma.

\section{III - O INSTITUTO DA OPERAÇÃO INTERLIGADA NA LEGISLAÇĀO DO MUNICÍPIO DO RIO DE JANEIRO}

1. No fértil panorama da realidade jurídica contemporânea, se insere, com coerência e consistência, o instituto da operação interligada, na configuração que a legislação carioca lhes empresta.

2. O instituto da operação interligada é. efetivamente, uma categoria jurídica típica do Direito Urbanístico, sob a forma do moderno 'urbanismo concertado'.

2.1. Envolve ele o balanceamento entre o interesse público e o interesse particular (art. $6^{\circ}$ ), sob a égide do Direito Edilício, que agasalha ambas as categorias, porquanto agregador do Direito Privado, do Direito Público e do Direito Social.

2.2. O primeiro desses interesses, encarnado pelo Poder Público, na qualidade de árbitro do mesmo. no campo dos Direitos Público e Social: e o segundo, do titular dos direitos de usar e de construir, como dominus da propriedade imobiliária urbana.

2.3. Tal como nos casos do solo criado e da transferência do direito de construir, e seguindo a irreversível tendência negocial analisada, do que resulta a nova postura do Poder Público; e ainda, a da consideração especial do caso concreto, regulou-se o instituto urbanístico da operação interligada, buscando a convergência dos mencionados interesses.

3. Cuidamos, especificamente, no presente estudo, da hipótese em que o ato de realização da operação interligada é de autoria do Prefeito Municipal.

3.1. Pelo disposto na Lei Rio $n^{\circ} 2.128 / 94$, em seu art. $7^{\circ}, l, c / c$ art. $6^{\circ}, l$ a competência do Chefe do Executivo Municipal, na matéria, circunscreve-se à hipótese em que a proposta (início da negociação) do interessado se caracterizar como de interesse píblico, conforme conceituação contida no $\$ 1^{\circ}$ do mesmo art. $6^{\circ} \mathrm{da}$ Lei.

4. O instituto urbanístico da operação interligada tem, no ordenamento juridico local, conforme antes indicado, sua base normativa nos arts. 28 e 29, e $\$ \$$, da Lei Complementar Rio $n^{\circ} 16$, de 04/06/92. que dispõe sobre a Política Urbana do Município e institui o Plano Diretor Decenal da Cidade do Rio de Janeiro.

4.1. Como já citado, prevê a $C F$, no seu art. 182 , e respectivo $\$ 1^{\circ}$, que o Plano Diretor 
"é o instrumento básico da política de desenvolvimento e de expansão urbana",

política essa para a qual a lei estabelece

"diretrizes gerais",

com o

"objetivo de ordenar o pleno desenvolvimento das funçōes sociais da cidade e garantir o bem-estar de seus habitantes."

4.1.1. O Plano Diretor expressa, ainda, as

"exigências fundamentais de ordenaçāo da cidade."

4.2. Em sede de reserva legal, constitucionalmente imposta, esses os lindes do Plano Diretor.

4.3. Nestes precisos limites, o Plano Diretor carioca, dispôs, de forma precisa, sobre operação interligada:

“Art. 28. Constinui operação interligada a alteraçāo pelo Poder Público, nos limites e na forma definidos em lei, de determinados parâmetros urbanísticos, mediante contrapartida dos interessados, igualmente definida em lei."

4.4. Como está claro, a Lei Complementar circunscreveu. com exatidão, o papel da lei ordinária: definir. em tese, os limites e a forma. ou seja, delimitar os contornos do contelido e o procedimento de efetivação do que chama de alteração de parâmetros urbanísticos; bem como definir. igualmente em tese, a configuração da contrapartida devida pelos interessados, respeitado o elenco que o art. 29, seguinte, enumera:

“Art. 29. Para efeito de utilização das operações interligadas serão estabelecidas as contrapartidas dos interessados, calculadas proporcionalmente à valorizaçāo acrescida ao empreendimento projetado, pela alteração de parâmetros urbanisticos, sob a forma de:

I - recursos para o Fundo Municipal de Desenvolvimento Urbano;

II - obras de infra-estrutura urbana:

IIl - terrenos e habitações destinados à população de baixa renda;

IV - recuperação do meio ambiente ou do patrimônio cultural."

4.5. O caráter negocial da operação interligada traduz-se nas figuras da proposta do interessado e na autorização do Poder Público: na negociação da contrapartida e na efe- tivação desta; no acerto das flexibilizações e na celebração de Termo de Compromisso (Lei Rio $n^{\circ} 2.128 / 94$, esp. arts. $1^{\circ} .2^{\circ}, \$ 1^{\circ}, 6^{\circ}, \mathrm{e}$ $\$ \$$ : e 16 a 18).

4.6. À Concretização da operação interligada o Plano Diretor qualifica, acertadamente, de sua realização $\left(\$ 1^{\circ}\right.$ do art. 29), evidenciando tratar-se de ato de execução administrativa, para o qual haverá sempre necessidade. segundo a própria lei, de assessoramento técnico ( $\$ 2^{\circ}$ do art. 29).

5. Neste moldura, a Lei Rio $n^{\circ} 2.128$, de $18 / 04 / 94$, regulou, pormenorizadamente, o instituto. quanto a seus limites e procedimento, e na definição da contrapartida, conforme prescrito pela Lei Complementar

6. No tocante à competência para a realização da operação interligada. foi prudente a lei ordinária.

6.1. Com efeito, quando a proposta do interessado for ao encontro do interesse público, poderá ela ser realizada por ato do Prefeito ou por lei; se o interesse particular for predominante, mas não inconveniente ao interesse puiblico. ou se for afastável eventual inconveniência a esse, a realização será exclusivamente por lei (art. $7^{\circ}, l$ e $I I$ ).

6.2. Mais ainda: mesmo nas hipóteses em que o ato pode ser do Prefeito. a lei estabeleceu um mecanismo de controle sucessivo pela Câmara Municipal consoante o estatuído pelos $\$ \$ I^{\circ}$ e $2^{\circ}$ do art. $7^{\circ}$ da Lei:

'... $\$ 1^{\circ}$. Quando a operação interligada for autorizada por ato do Prefeito, a execução deste poderá ser sustada pela Câmara Municipal, no prazo improrrogável de sessenta dias contados da data de sua edição, através de decreto legislativo que enunciará, obrigatoriamente, as razões da impugnação do ato.

$\$ 2^{\circ}$. O ato do Prefeito relativo à operação interligada só produzirá efeitos e gerará direitos após decorrido o prazo referido no parágrafo anterior, o qual será interrompido nos periodos de recesso da Câmara Municipal."

6.3. Anote-se, desde logo, que, quer ato do Prefeito, quer lei trata-se, materialmente, de ato administrativo, de realização do direito, como refere a legislação citada.

7. O atual art. 236 da Constituição do Es- 
tado do Rio de Janeiro - antigo 233 estabelece:

"Art. 236. A lei municipal, na elaboração de cujo projeto as entidades representativas locais participarão, disporá sobre o zoneamento, o parcelamento do solo, seu uso e sua ocupação. as construções e edificaçōes, a proteção ao meio ambiente, o licenciamento, a fiscalização e os parâmetros urbanísticos básicos objeto do plano diretor."

7.1. Refere-se o texto constitucional, neste artigo, à lei municipal ordinária, que pormenorizará o disposto no Plano Diretor, inclusive quanto aos 'parâmetros urbanísticos básicos' objeto do mesmo.

7.2. Ora, é o próprio Plano Diretor que contempla o instituto da operação interliga$d a$, e admite que a lei municipal ordinária estabeleça limites e forma, definindo a respectiva contrapartida, da alteração, pelo Poder Público,

"de determinados parâmetros urbanísticos".

7.2.1. É o que a Lei Rio $n^{\circ} 2.128 / 94$ faz, em perfeita consonância, portanto, com a Lei Complementar, que aprovou o Plano Dirtetor, e com o art. 236 da Constituição do Estado.

8. É importante atentar-se para a redação do art. 28 do Plano Diretor.

8.1. Quando quer ele que seja a lei ordinária que trate do assunto, ele o diz expressamente, e, por duas vezes, no mesmo contexto articulado: (a) para definir os limites e a forma das alterações: (b) para definir a contrapartida dos interessados.

8.2. Ao se referir à adequação concreta, no caso individualizado, o dispositivo, sugestivamente. emprega a expressão Poder Público, como agente da alteração, e, portanto, da realização da operação interligada.

9. Por sua vez, o parágrafo único do art. 423 da Lei Orgânica Municipal dispõe:

" $O$ exercicio do direito de propriedade $e$ do direito de construir fica condicionado ao disposto nesta Lei Orgânica e no plano diretor e à legislação urbanística aplicável."

9.1. Ora, tanto o Plano Diretor, quanto a lei urbanística aplicável, a Lei Rio n' 2.128/94, consagram o instituto urbanístico da operação interligada, e a última prevê a competên- cia do Prefeito, para a sua realização, na hipótese que aponta.

10. Verifica-se, assim, que nem o dispositivo constitucional estadual, nem o orgânico municipal estabeleceram qualquer espécie de reserva legal que interfira no caso.

11. Os atos, materialmente administrativos, de realização do direito são, salvo disposição normativa hábil em contrário, da competência do Poder Executivo, que é o Poder Administrativo por excelência.

11.1. É que, assim como há a reserva legal, existe a reserva administrativa.

11.2. Inocorre, na hipótese, delegação legislativa, sob a forma de devolução ao Executivo, quando, através de ato não-normativo, concreto, realiza a operação interligada.

12. Há-de entender-se, primeiramente, de forma adequada, a cláusula alteração de parâmetros urbanísticos.

12.1. Gize-se, para fins de sistematização, que existem os direitos de usar e de construir, como poderes inerentes ao domínio imobiliário, em princípio livres, com seu exercício condicionado ao respeito aos direitos de vizinhança e ao regulamentos administrativos, e informados pela função social da propriedade.

12.2. No campo do Direito Edilício, surgem as limitações ao exercício desses direitos, legalmente disciplinadas, e que só podem ter uma finalidade, qual seja a da consecução do interesse público.

12.3. Ora, a lei que disciplina as limitações, pode prescrever, como na operação interliga$d a$, que, se o que consulta ao interesse público, no caso concreto, é a flexibilização de determinada limitação, o Poder Executivo, dentro dos lindes legalmente estabelecidos, obedecido o procedimento adequado e mediante a contrapartida devida, igualmente dentro das fronteiras estabelecidas pela lei, tem competência para, por ato concreto, de atender a essa situação específica.

12.4. Quem legislou sobre o instituto da operação interligada foi a Câmara, com a sanção do Prefeito: este, ao praticar o ato de realização, estará executando a lei, e não 
exercendo função normativa, seja legislativa, seja regulamentar.

12.5. Na realização da operação interligada, a Lei $n^{\sim} 2.128 / 94$ estabelece detalhados limites e condicionamentos, prescreve o respectivo procedimento e faz as definições exigidas pelo Plano Diretor: o ato de concretização é que é, na hipótese de consultar ao interesse público, atribuído ao Poder Executivo.

13. O que ocorre, pois, é, por via legislativa a previsão, de um lado, de limitações; e, de outro, de sua exclusão parcial, após a aferição de determinadas condições e o cálculo da contrapartida, no caso.

13.1. Comparemos com o Direito Penal.

13.1.1. A lei comina a sanção em relação a determinada conduta com certo resultado.

13.1.2. Mas ela própria exclui a antijuridicidade, em casos como o da legítima defesa do estado de necessidade, do exercicio regular de direito (Código Penal, art. 23, sob a ementa 'Exclusão de ilicitude').

13.1.3. Cabe ao Juiz apreciar a caracterização. ou não, da excludente no caso concreto, e ele nāo estará, certamente, legislando.

A ele compete dar vida aos contornos fluídos que envolvem a noção de regularidade no exercício do direito (art. 23, III) e as definiçōes de estado de necessidade (art. 24, e $\$ \$$ ), e de legítima defesa (art. 25), inclusive com a possibilidade de aplicação de pena, em certas hipóteses (arts. 23, parágrafo único, $\mathrm{e}$ $24, \S 2^{\circ}$ ).

14. Nesta linha, o ato administrativo que é praticado, pelo Prefeito Municipal, é o de autorização.

14.1. Ora, a designação é exata, porque $a u$ torização, em Direito Administrativo, é o ato que faculta determinada atividade que, sem ela seria vedada, ficando o destinatário habilitado a exercer tal atividade a que estava impedido por disposição legal.

14.2. O. B. BANDEIRA DE MELLO (Principios Gerais de Direito Administrativo, Rio, Forense, 1969, I: 493) explica:

"Ela deve ser dada para cada caso em particular, quando surge a faculdade do in- teressado de agir, ao contrário da norma legal a respeito."

14.3. Está ela na trilha de outros atos que o brilhante jus-administrativa catologa - como a dispensa, em caso de obrigação positiva -. e que o Direito Administrativo sempre conheceu e reconheceu como atos constitutivos de direito, de natureza concretizada, atos que eximem, o administrado, de limitaçōes, ônus e encargos; excluindo a antijuridicidade de determinada atividade.

15. Com a moderna concepção, antes exposta, de que a norma jurídica nasce da conjugação da incidência da regra de direito com o exsurgimento da energia jurídica que brota do próprio substrato factual identifica-se, na execução da lei, em face do caso concreto, o que J. J. GOMES CANOTILHO (Direito Constitucional, Coimbra, Almedina, $5^{2}$ ed., 1992, p. 229) qualifica de norma de decisão.

15.1. Em verdade, da decisão, no caso concreto, emerge a norma, em sua plenitude, que àquele preside.

15.2. O renomado constitucionalista desenvolve este ponto (ib.):

" Uma norma jurídica adquire verdadeira normatividade quando com a 'medida ordenação' nela contida se decide um caso jurídico, ou seja, quando o processo de concretização se completa através da sua aplicação ao caso jurídico a decidir mediante: (1) a criação de uma disciplina regulamentadora (concretização legislativa, regulamentar etc.); (2) através de uma sentença ou decisão judicial (concretização judicial); (3) através da prática de actos individuais pelas autoridades (concretização administrativa). Em qualquer dos casos, uma norma juridica que era potencialmente normativa ganha uma normatividade actual e imediata através da sua 'passagem' a norma de decisão que regula concreta e vinculativamente o caso carecido de solução normativa."

15.3. E aduz:

"Se a forma jurídica só adquire verdadeira normatividade quando se transforma em norma de decisão aplicável a casos concretos, concluiu-se que cabe ao agente ou agentes do processo de concretização um papel fundamental, porque sāo eles que no fim do pro- 
cesso, colocam a norma em contacto com a realidade."

15.4. Conclui, a seguir (p. 230):

"Num Estado de direito democrático, o traballo métódico de concretiąação é um trabatho normativamente orientado. Como corolários subjacentes a esta postura metodológica assinalam-se os reguintes:

1) O jurista concretizador deve trabalhar a partir do texto da norma, editado pelas entidades democrática e juridicamente legitimadas pela ordem constitucional.

2) A norma de decisão, que representa a medida de ordenação imediata e concretamente aplicável a um problema, não é uma 'grandeza autônoma', independente da norma jurídica, nem uma 'decisão' voluntarista do sujeito de concretização; deve, sim, reconduzir-se sempre à norma jurídica geral. A distinção positiva das funções concretizadoras destes vários agentes depende. como é óbvio, da própria Constituição, mas não raro acontece que no plano constitucional se verifique a comvergência concretizadora de várias instâncias:

a) níel primário de concretização: os principios gerais e especiais, bem como as normas da constinuição que 'densificam' outros princípios (cf. Supra, Cap. 4, A, 4);

b) nivel político-legislativo: a partir do texto da norma constitucional os órgãos legiferantes concretizam, atrav'és de 'decisóes políticas' 'om densidade normativa - os actos legislativos - os preceitos da constituição;

c) nivel executivo e jurisdicional: com base no texto da norma constitucional e das subseqüientes concretizações desta em nível legislativo (também em nivel regulamentar, estatutário étc.), desenvolve-se o trabalho concreti-ador, de forma a obter uma norma de decisão solucionadora dos problemas concretos. "

15.5. Toda essa nova visão torna superada a rígida distinção entre normatizar e decidir. pelo que, cada vez mais, se deixa, a este último. a completação do primeiro, com a proliferação. sadia e fértil, das regras em branco; das regras de contéido aberto, como é o caso.

15.6. CANOTILHO (ib.) acentua, com propriedade. este ponto, ao enfatizar a necessi- dade de diferentes núveis de realização ou concretização - legislativo, administrativo. judicial -.. para que a regra juridica, inclusive a constitucional, chegue à realidade. mesmo porque, seja ela de caráter aberto, indeterminado, polissêmio; seja rígido, haverá sempre necessidade, não apenas de interpretaçāo. mas de completação.

15.7. Como é curial, até mesmo no Direito Penal, tão cioso do princípio da legalidade. sob a modalidade da resen a legal, do mullum crimen sine lege, da tipicidade. existem: (a) as regras de contelido aberto, que exigem a completação por seu executor: (b) a norma penal em branco, que é integrada por meio de regulamento do Executivo: (c) a própria dosagem da pena cominada entre uin máximo e um mínimo, por seu aplicador.

15.7.1. Os conceituados penalistas, EUGENIO RAÚl ZAFFARONI e JOSÉ HENRIQUE PIERANGELI (Manual de Direito Penal Brasileiro, Parte Geral, São Paulo, RT, 1997, p. 448 e s.) fazem, a propósito, considerações relevantes.

15.7.1.1. Mesmo os sistemas penais, como o nosso. que se fundam nos tipos legais, não podem fugir às dificuldades em precisarem-se certos limites da tipicidade. mesmo nos tipos fechados, que, em princípio, se bastariam a si mesmos: bem como adotam os tipos abertos, em que não se individualiza totalmente a conduta, exigindo que o aplicador o faça, recorrendo a pautas ou regras gerais que fora da regra aplicada e, com isso. "feche" o tipo.

15.7.1.2. Como forma de abertura normativa, citam aquela em que o preceito legal envolve alguma espécie de gradação ou de quantificação, e a mensuração fica com o aplicador, porque a precisão só pode ser feita conforme as circunstâncias no caso concreto.

15.7.1.3. Quanto à norma em branco (que ñ̃o existe, apenas, no Direito Penal), salientam que não é ela inconstitucional, não há nela delegação legislativa, nem afronta à re. sen a legal, exatamente pela divisão de Poderes do Estado.

15.7.1.4. Já assinalamos, a propósito, o princípio da reserva administrativa.

Neste sentido, a norma em branco não rom- 
pe esta divisão, mas, pelo contrário, a respeita, porque o Executio também tem seu espaço próprio.

Lembremos que. exatamente na área do direito de construir. o art. 572 do Código Civil. ao remeter-se aos regulamentos administratilos. criou o que tem sido considerado uma norma civil em branco.

16. Nesta linha de desmistificação da distinção rígida entre normatizar e concretizar, acentuemos a natureza do regulamento:

a) o ato de regulamentar já é o primeiro passo do executar, tanto que os arts. $84, I V$. e 87 . II, da $C F$. aludem à regulamentação para a execuçāo das leis.

b) o regulamento é. tão-somente, a antecipaçāo do entendimento que o administrador público teria no caso concreto: ao invés de limitar-se a administrar in casu, o administrador se antecipa. dispondo sobre a sua própria conduta no cumprimento de seus deveres e obrigaçōes, e no exercício de seus direitos. poderes e faculdades. autovinculando-se com essa antecipação.

17. Aspecto importante a ser considerado, a fim de se evitarem erronias muito comuns, é que o princípio da legalidade, a que está submetido o administrador público ( $C F$, arts. $37 e 70)$ não se confunde com a reserva legal.

17.1. É que, se no Direito Penal - e já sublinhamos as questōes pertinentes -, a reserva legal conduz à tipicidade, o principio da legalidade administrativa não o faz.

17.2. Seria impossível, na realidade, que o legislador descrevesse, de antemão, de modo completo, como a administraçāo pública teria de agir sempre.

17.2.1. Ao administrador público são facultadas opçōes, dentro dos limites da lei.

17.2.2. Com efeito, o Poder Público, no exercício da atividade administrativa, atua de modo diversificado, em condiçōes juridicas diferenciadas. Genericamente, estes vários modos e condições podem ser distribuídos em duas categorias básicas de açōes administrativas: uma ação regrada e uma ação discricionária. como é sabido.

17.2.3. A função administrativa não se esgota dentro do preestabelecido em lei, pois que, no contrário, o administrador estaria in- capaz de cumprir, plenamente, seus encargos. múltiplos e variados. Existe, destarte. uma área da administração pública. no sentido funcional, que escapa ao precondicionamento legal e absoluto, ficando na discrição do administrador. que, assim, se autodetermina, visando ao melhor para o interesse público.

17.2.4. Raríssimos, sabemos, são os atos inteiramente vinculados ou regrados.

$\mathrm{O}$ ato administrativo compōe-se, essencialmente, de aspecto vinculado e mérito, que é a medida do poder discricionário.

Balizam a discricionariedade os parâmetros, dentre outros, da consonância com o interesse público, da razoabilidade, da proporcionalidade, da técnica.

17.3. No caso da operaçāo interligada. o que existe. essencialmente, é a discricionariedade técnica. e. daí, o assessoramento de que tem, obrigatoriamente, de valer-se o Poder Público para a sua realização.

17.4. A abertura. ao administrador. do espaço da discricionariedade, pelo legislador, nunca foi - nem poderia sê-lo — entendida como delegação legislativa. nem que o administrador ficaria sem controle, no caso, aliás, expressamente configurado.

17.4.1. É que, segundo FRITZ FLEINER, "a questão de saber onde começa o domínio do poder discricionário e onde ele termina é, por si mesma, uma questão jurídica, e não de apreciação".

17.4.2. Destarte, o legislador traça, como no caso, os limites do branco que é deixado ao administrador: a circunferência do círculo interno na famosa figuração gráfica dos círculos concêntricos, representativa do interrelacionamento entre a vinculação e a discrição administrativas.

17.4.3. Por seu turno, o Judiciário tem competência. para aferir se o administrador se pautou dentro dessa demarcação.

17.4.4. FRANCISCO CAMPOS (Direito Administrativo, Rio. Freitas Bastos) assinala a existência dos limites do poder discricionário:

"A ação administrativa discricionária é limitada externa e internamente. Externamente o seu limite consiste na ordem jurídica em cujo quadro se desenvolve a atividade admi- 
nistrativa e, particularmente, na existência de interesses juridicamente protegidos, ou de direitos subjetivos dos administrados. Além desses limites externos, a ação discricionária encontra limites interiores que consistem. precisamente, no fato de que os conceitos indeterminados em que se funda o juizo discricionário dispõem, ainda que imprecisos. de um limite superior e de um limite inferior. Por maior que seja a liberdade de apreciação, própria do juizo discricionário, é sempre possivel mostra-se claramente que a conclusão excede um dos limites"

17.5. Na prática da operação interligada, a par dos pareceres técnicos, das justificativas que embasam e motivam o ato administrativo, do balizamento dos pormenorizados limites $\mathrm{e}$ condicionamentos, materiais e procedimentais, nos termos da lei, estará o ato de realização concreta sempre bitolado pelos parâmetros da razoabilidade, da proporcionalidade. da moralidade, da legitimidade, da economicidade.

17.5.1. A operação interligada está sujeita a pressupostos e requisitos de legalidade, estabelecidos pelo legislador: e a discrição é do tipo objetivo, pois que a margem de apreciação é delimitada, inclusive quanto à existência de interesse público na realização da operação, eis que ela será efetuada somente nos casos em que houver interesse público que justifique a flexibilização dos parâmetros, ou seja, interesse público tão ou mais relevante eu o expresso pela limitação normativamente imposta.

\subsection{2. É básico esse aspecto.}

No procedimento da operação interligada busca-se balancear o interesse público estritamente traduzido na regra limitativa; e outro interesse público, cuja consecução seria frustrada, se mantido o anterior.

17.5.3. Ademais, conforme acentuado, o controle, pela Câmara, está expressamente previsto na Lei.

17.5.4. Trata-se, efetivamente, de controle — e não de simples fiscalização -, porquanto há ingerência direta da atuação, do Legislativo, na do Executivo, pelo poder, do pri- meiro, de sustar a eficácia do ato praticado pelo segundo.

17.5.5. Acentue-se a transparência princípio básico da Moderna Administração Pública - do procedimento de realização da operação interligada, que prevê a participação dos proprietários dos imóveis lindeiros, nos termos do arr. 20 da Lei $n^{\circ} 2.128 / 94$ e do art. 436, II, da Lei Orgânica Municipal.

18. Sublinhe-se que todo "urbanismo concertado" tem por base, no processo de individualização fático-juridica, a diferenciação específica, a flexibilizaçāo de parâmetros edilícios.

18.1. Os negócios jurídicos praticados, como no caso, são onerosos, havendo sempre contraprestaçāo, inclusive sob a modalidade de preço (é a hipótese da contrapartida, na operação interligada), sem caráter tributário.

18.2. Já em Seminário realizado na Cidade de São Sebastião, em 25/26 de junho de 1976, a partir de documento produzido pela Função CEPAM, um dos postulados expressou que o proprietário poderá "obter onerosamente do Poder Público licença para edificar mais".

É esta a realidade do Direito Urbanístico Contemporâneo.

19. Outra anotação que se impõe é que, mercê da nova configuração dada à autonomia municipal, pela Constituiçẫo Federal, caracterizando o Município, inquestionavelmente, como ente político-federativo e assegurando-lhe a capacidade de auto-organização (art. 18), não é da alçada da Constituição do Estado dispor sobre a competência dos Poderes Políticos dos Municipios, matéria reservada à Lei Orgânica (art. 29), sendo que é preceito imperativo, da Carta Magna Federal, a

"organização das funçōes legislativas e fiscalizadoras da Câmara Municipal" (inciso $X I)$.

19.1. É certo que o caput do art. 29 da $C F$ estatui que a Lei Orgânica do Municipio deverá atender ao princípios estabelecidos na Carta Magna Nacional e na Constituição do respectivo Estado, mas princípios näo são 
regras específicas sobre determinada matéria.

19.2. Aliás, anote-se que a Constituição do Estado, no seu Título IX, 'Da Organização Municipal", não trata da competência da $C a ̂$ mara Municipal.

19.3. De qualquer modo, conjugando-se o modelo federal ( $C F$, art. 49, X), o estadual (art. 99, X) e o citado preceito do art. 29, XI, da $C F$, é inarredável a competência, não só de fiscalização stricto sensu, mas também de controle, do Legislativo, em relação aos atos do Poder Executivo.

19.4. Realça-se, assim, na CF, a discriminação entre a função legislativa e a função fiscalizadora e controladora da Câmara $\mathbf{M u}$ nicipal.

19.5. Essa última espécie de atuação é que a Câmara exerce quando susta o ato do Prefeito de realização da operaçāo interligada, consoante o previsto nos $\$ \S 1^{\circ}$ e $2^{\circ}$ do art. $7^{\circ}$ da Lei Rio $n^{\circ} 2.128 / 94$.

20. É fundamental acentuar que o Egrégio TRIBUNAL DE JUSTIÇA DO ESTADO DO RIO DE JANEIRO já chancelou o instituto da operação interligada, ao declarar inconstitucional a Lei Rio $n^{\circ} 1.665 / 91$, que dispôs sobre a criaçāo do Conselho Municipal de Política Urbana - COMPUR (Representação de lnconstitucionalidade $n^{\circ} 43 / 98$, julg. em. 15/03/99, DO-RJ-III, 09/04/99), na medida em condicionava a aprovação da operação interligada ao parecer favorável do citado órgão colegiado.

A decisão concluiu:

"A criação de um Conselho Administrativo cujas decisões sejam condicionantes às do
Prefeito, contraria o perfil organizacional modelado pela Constituição do Estado do Rio de Janeiro, extensivel aos municípios que o integram."

\section{IV - CONCLUSÃO}

1. Em face do exposto, opinamos em que nenhum vício de constitucionalidade macula a Lei Rio $n^{\circ} 2.128$, de 18104/94, por atribuir, ao Prefeito Municipal. mediante a prática de ato administrativo negocial, a realizaçāo concreta da operação interligada, nos casos em que a proposta do interessado consulta ao interesse público.

2. Conforme se demonstrou, o instituto, na configuração da legislação carioca, está em perfeita consonância com o disposto na Constituição Federal, na Carta Política Estadual e na Lei Orgânica do Município; e com exatidão inserido no universo contemporâneo dos Direitos Privado. Público e Social, com seus desdobramentos nos Modernos Direitos Constitucional, Administrativo, Civil, Urbanístico e Edilício.

3. Atende, adite-se, com pertinência, à convergência dos interesses público e do particular, na linha do reconhecimento de que o Direito só se aperfeiçoa no caso concreto, para cuja valoração o Poder Executivo e, por excelência, habilitado.

Rio de Janeiro, 20 de julho de 2000

SERGIO DE ANDRÉA FERREIRA - Advogado

OAB-RJ n 79.890 (OAB-GB n' 11.417) 